The Quarterly Journal of Austrian Economics

Volume 23 | NO.3-4 | 568-612 | Fall/Winter 2020 WWW.QJAE.ORG

\title{
INSTITUTIONS AND ENTREPRENEURSHIP: Pushing THE BOUNDARIES
}

\author{
Scott Burns and Caleb S. Fuller*
}

JEL Classification: H35, L5, M13, O31, P14

Abstract: New institutional economics (NIE) and Austrian economics (AE) both emphasize the role that institutions play in facilitating or impeding entrepreneurship and hence economic growth. In this paper, we discuss the complementarities between AE and NIE for advancing our understanding of the relationship between institutions and entrepreneurship. We argue that a subjectivist view of institutions, entrepreneurial microfoundations, and capital heterogeneity can enrich our understanding of within-country variation in entrepreneurial strategies, institutional evolution, and the relationship between institutions and production processes. We hope our discussion serves as an invitation both for further theoretical collaboration between the two camps and as a spur to applied research at the intersection of institutions and entrepreneurship.

\footnotetext{
Scott Burns (scott.burns@selu.edu) is assistant professor of economics at Southeastern Louisiana University. Caleb S. Fuller is assistant professor of economics at Grove City College.

We thank Ennio Piano, David Lucas, Jeff Herbener, Rosolino Candela, and Chris Coyne for helpful commentary. We are also grateful to two anonymous referees and the editor for insightful remarks. The standard disclaimer applies.
}

Both authors shared equally in the writing of this paper. 


\section{INTRODUCTION}

Tew institutional economics (NIE) has made important contri1 butions to our understanding of the relationship between institutions and entrepreneurship. ${ }^{1}$ NIE scholars stress the critical function that institutions - society's "rules of the game" - play in constraining and enabling entrepreneurial action (North 1986; Baumol 1990; Murphy et al. 1991; Williamson 2000). Austrian scholars have also written extensively about institutions and entrepreneurship, work that predates the mid-twentieth-century advent of NIE. Beginning with Carl Menger's ([1871] 2007; 1883) analysis of the spontaneous emergence of social orders, as well as Ludwig von Mises's ([1920] 1990) and F. A. Hayek's $(1945 ; 1948)$ comparative analyses in the socialist calculation debate, Austrians have always been concerned with how choice generates institutions and how these institutions influence social outcomes in turn (Lavoie 1985; Langlois 1986, 1992, 165; Foss 1997; Garrouste 2008). Especially in the twentieth century, Austrians have also stressed the central role that entrepreneurs play as the "driving force" of the market process (Mises [1949] 1998; Hayek 1968; Kirzner 1973; Klein and Bylund 2014; Bylund 2019).

Given these overlapping themes, it is unsurprising that there has been some collaboration between the traditions. At the same time, it is also surprising that this exchange of ideas has not been more thoroughgoing. Numerous authors have suggested that there are gains from trade to be had from merging aspects of each tradition (see Langlois 1986, 1992; Boettke 1989; Foss 1994, 1997; Boettke and Coyne 2003, 2009; Sima 2004; Foss and Klein 2009; Manne 2014; Bylund and McCaffrey 2017; McCaffrey 2018; Piano and Rouanet 2020). These contributions represent promising movements in the direction of integration; nevertheless; we believe that there remain unseized profit opportunities from further integrating the two traditions to improve our understanding of the institutions-entrepreneurship link.

\footnotetext{
${ }^{1}$ The term institutional economics is probably now more commonly used than is NIE, but we prefer NIE nomenclature to distinguish from old institutionalism. Eggertsson (1990) draws a distinction between neoinstitutional economics and new institutional economics, with the latter rejecting more of the "hard core" of neoclassical economics. While recognizing the differences between many contemporary institutional thinkers, we do not draw that distinction.
} 
This paper identifies three areas where NIE literature on entrepreneurship may benefit from more thoroughly incorporating Austrian insights. The first deals with a recent puzzle in NIE literature: explaining within-institution variations in entrepreneurial strategy--that is, why some entrepreneurs abide by existing rules while others seek to alter or evade them. The second deals with a subject that prominent NIE scholars such as Douglass C. North (1994) contend has not been satisfactorily resolved: explaining why and how institutions evolve over time. The third area addresses an even less well-established but promising research stream: the interaction between institutions, capital heterogeneity, and entrepreneurial action.

Suggesting how long-established Austrian insights can enrich NIE thinking on entrepreneurship is not to imply that the influence should be unidirectional. As this paper will demonstrate, Austrians can also incorporate NIE ideas in several areas. These include extending well-developed Austrian notions of entrepreneurship beyond "productive activity" and the adoption of new approaches which emphasize the distinction between "economic" and "legal" property rights.

This article achieves three tasks. First, it demonstrates the overarching complementarity between Austrian economics and NIE, particularly for furthering understanding of the institutions-entrepreneurship "black box." Second, it highlights existing work that points in the direction of synthesis. Third, it proposes future research avenues based on our proposed integration of the traditions. The objective here is not to provide a comprehensive overview of the ways that these traditions can benefit from each other, nor is it to provide a final word on the proposed research ideas. However, the hope is that this article will spur further collaboration between the two traditions that will help resolve ongoing puzzles in the entrepreneurship literature.

The article proceeds as follows. First, the elements of both Austrian economic (AE) and NIE that are crucial for better understanding institutions and entrepreneurship are reviewed. A discussion of the prior interaction between the two traditions follows, and some ways in which they can complement each other are suggested. The final section builds on that synthesis to identify concrete ways that Austrian ideas can inform our approach to questions at the 
intersection of institutions and entrepreneurship. In doing so, it also raises several questions which will hopefully inspire future research. The article concludes with implications.

\section{AUSTRIAN ECONOMICS AND NIE-KEY THEMES FOR ENTREPRENEURSHIP}

\section{Austrian Economics}

Austrian economics is marked by its subjectivist foundations. Of course, all contemporary economic traditions recognize the subjective nature of value, though the Austrian emphasis is the most thoroughgoing (Stringham 2010). ${ }^{2}$ A key aspect, though, of the Austrians' encompassing subjectivism has been to show that each person evinces not merely different preferences, but also divergent knowledge and expectations. Unsurprisingly, then, Austrians have been the most systematic exponents of subjectivism within economics, an emphasis that extends to Austrian theorizing on entrepreneurship and management (Klein et al. 2008, 4).

The subjective nature of knowledge is likely the most widely recognized aspect of Austrian subjectivism. In his much-cited 1945 paper, Hayek argued that prices serve as knowledge surrogates since "local knowledge" is not given in its totality to any single mind; rather, it is dispersed throughout society in the minds of individuals. ${ }^{3}$ As Hayek emphasized, this knowledge "of the particular

\footnotetext{
${ }^{2}$ Hayek $(1955,52)$ famously quipped, "it is probably no exaggeration to say that every important advance in economic theory during the last hundred years was a further step in the consistent application of subjectivism."

${ }^{3}$ Salerno (1990) initiated a debate, centered on the calculation literature, regarding the similarities and differences between Mises and Hayek. Specifically, Salerno (1990, 1993, 1994), Rothbard (1991), Herbener (1996), and Hülsmann (1997) argue that Mises' emphasis on monetary calculation was substantively different from Hayek's emphasis on knowledge dispersion. Although conceding some points advanced by the "dehomogenizers," such as the renewed emphasis given to forward-looking appraisement, Yeager (1994), Kirzner (1996), Boettke (1998), and Horwitz $(1998,2004)$ argue that such a position rests on the tenuous (in their view) idea that Hayek treats prices as "sufficient statistics" in the neoclassical sense (also see Stalebrink 2004). Although these differences in interpretation are worth noting, any further adjudication of this debate is beyond the scope of this paper, as we see both sides as likely being amenable to the insights offered here.
} 
circumstances of time and place" can only be discovered in the context of a market economy.

Although Austrians have consistently integrated subjectivism with their theories of value, knowledge, expectations, and even capital (described below), they arguably have not applied it as thoroughly to institutions. This gap is puzzling given that many of the most seminal Austrian contributions (i.e., the emergence of money and law, the socialist calculation debate) either explained the origins of institutions or engaged in comparative institutional analysis (Menger [1871] 2007; 1883; Mises [1920] 1990, [1949] 1998; Hayek 1945, 1948). These contributions were deeply rooted in subjectivism, as they sought to explain real-world institutions in terms of the personal values and knowledge of the relevant actors. (The way that further application of subjectivism to institutions can provide answers and generate new research directions at the interchange of institutions and entrepreneurship is described below.)

The Austrian tradition is also widely recognized for its pioneering work on entrepreneurship and the central role accorded to entrepreneurs in driving the competitive market process (Mises [1949] 1998; Kirzner 1973; Boettke and Coyne2003; Foss et al. 2008; Klein and Bylund 2014). ${ }^{4}$ Austrians eschew static general equilibrium models, with their assumptions of perfect information, which dominate neoclassical economics. ${ }^{5}$ Instead, they favor a dynamic, processoriented approach —one that emphasizes how entrepreneurs utilize their unique knowledge while responding to continuous profit and loss feedback. Mises ([1949] 1998, 249) famously described the entrepreneur as the "driving force" of this process, the catalyst of change who drives the dynamism of the market economy. Whereas the defining feature of long-run equilibrium in the neoclassical approach is zero economic profits, Austrians place the ceaseless

\footnotetext{
${ }^{4} \mathrm{~A}$ formalistic approach to entrepreneurship has gained traction in the mainstream economics profession. For example, Lazear (2004) offers a formal model of entrepreneurship with the primary prediction being that "generalists," rather than "specialists," will become entrepreneurs.

${ }^{5}$ The Austrian conception of the "evenly rotating economy" is an analogue to "general equilibrium," though Austrians do not derive welfare implications from this construct, nor is it held as being attainable in the real world. Still, Cowen and Fink (1985) have criticized this construct.
} 
earning of profit and loss at the forefront of the dynamic market process (Mises [1922] 1951).

Austrians have advanced somewhat differing perspectives on the so-called market process. For Israel M. Kirzner (1973, 1996, 1997, 2009), the market process describes entrepreneurs' ceaseless attempt to seize profits, which via arbitrage, continually drive disequilibrium states toward equilibrium. Continuous learning is key to this framework. Joseph T. Salerno $(1993,1994)$ argues for a narrower conception of market process that emphasizes how those less skilled at forecasting the future are continuously and systematically weeded from the marketplace. Arguably, both of these ideas find textual justification in Mises ([1949] 1998, [1922] 1951), but what these varying conceptions share in common is that entrepreneurs, responding to profit and loss, are the primary drivers of this competitive process, once more standing in sharp contrast to general equilibrium models, where, based on the assumptions, the entrepreneur has no role to play.

A corollary of market process analysis is that entrepreneurial decision-making cannot be characterized by stochastic models, where outcomes are unknown but which are drawn from a known probability distribution. Instead, it is better characterized by the uncertainty described by Frank Knight (1921), ${ }^{6}$ where the distribution of possible outcomes is itself unknown. Entrepreneurs therefore act under conditions of uncertainty, drawing on their subjective knowledge to anticipate opportunities, a function eliminated by static equilibrium models that assume perfect information and thus preclude genuine uncertainty (Mises [1949] 1998, 249-56).

The speculative function of entrepreneurship is a universal human function, not a job title or characteristic of a subset of individuals (Klein 2008). This universal speculative element owes to the fact that action is future oriented, that the future is uncertain, and that all actions therefore confer either psychic profits or losses. At the same time, the Austrian tradition also designates a specific set of economic actors as "entrepreneurs," in contrast to wage earners, landowners, or consumers. In the Austrian framework,

\footnotetext{
${ }^{6}$ Klein (2010) discusses the overlap between Knight's and Mises's approaches to entrepreneurship and uncertainty.
} 
entrepreneurship is the element which organizes and arranges the factors of production but is not a factor of production itself.

This basic conception of the entrepreneur has generated a flurry of literature attempting to demonstrate that "innovation" (Schumpeter 1934), “alertness" (Kirzner 1973; Sautet 2018), "judgement" (Foss and Klein 2012), or "creativity" (Alvarez and Barney 2007) is the essence of the entrepreneurial function. These debates have important implications for market theory and for integrating entrepreneurship with organizational economics, but they have less direct bearing on the interface between institutions and entrepreneurship that is central to NIE literature. We concur with Matthew McCaffrey $(2018,190)$ that "a major advantage of [William J.] Baumol's argument is that its value does not depend on any particular theory of entrepreneurship." To that end, entrepreneurship is here defined as "profit seeking"—a "big tent" description broad enough to capture all major conceptions. Additionally, the phrase "entrepreneurial action" is often used, because "discovery," "judgment," and "creation" all require subsequent action for there to be any real-world impact.

Austrians have also long stressed the heterogeneity of capital, an emphasis that begins with Menger's ([1871] 2007) development of an intricate capital-or production-structure. At least until the emergence of certain NIE concepts, Austrians were unique in stressing that capital is heterogeneous not only in form but also in function (Lachmann [1956] 1978; Lewin 1998; Garrison 2001). As Ludwig M. Lachmann ([1956] 1978, 2) argued, heterogeneity in function, or "use," refers to the multiple specificity of capital goods, meaning that "each capital good can be used for a limited number of purposes." Capital goods also vary according to their complementarity with other capital goods, a point that is implicit in Hayek's (1945) argument. Knowledge of the "particular circumstances of time and place" includes the degree to which capital goods (and labor) are substitutable for one another.

As with subjectivism, capital heterogeneity and entrepreneurship are inextricably linked. Entrepreneurs must continuously allocate capital goods to what they perceive is their most profitable use, which requires that they judge their complementarity (Mises [1949] 
1998, 252-254; Lachmann [1956] 1978; Foss 2012). ${ }^{7}$ The heterogeneous attributes of capital goods must first be subjectively perceived and interpreted by entrepreneurs before they can be integrated into their production plans (Kirzner 1966). A key aspect of entrepreneurship, then, is exercising judgment over how to best combine and utilize heterogeneous capital goods (Foss et al. 2007). As Lachmann ([1956] 1978, 16) notes, "As long as we disregard the heterogeneity of capital, the true function of the entrepreneur must also remain hidden."

\section{New Institutional Economics}

NIE arose in the latter half of the twentieth century as an effort to revive core elements of classical political economy and to return institutions to the forefront of economic analysis. Rooted in Ronald $\mathrm{H}$. Coase's seminal contributions $(1937,1960)$, the term new institutional economics was coined by Oliver E. Williamson in 1975. NIE, which came to represent an amalgam of transaction cost, property rights, law and economics, public choice, and agency theorizing, blossomed around the time the Austrian tradition was experiencing its own revival, sparked by seminal publications (Rothbard [1962, 1970] 2009; Kirzner 1973), the famed South Royalton conference in 1974, and Hayek's Nobel Prize in 1974. NIE scholars frequently addressed institutional issues that, with a few notable exceptions, were not systematically examined by Austrians in the decades between the Keynesian Revolution and the Austrian revival (Foss and Klein 2009). Coase and Williamson devised transaction cost theories of the firm and other organizations. Armen A. Alchian and Harold Demsetz (1972), Steven N. S. Cheung (1983), and Yoram Barzel (1997) offered somewhat differentiated transaction cost theories of the firm, while also seeking to explain how alternative property rights arrangements affect and are affected by economic activity. ${ }^{8}$ North and Baumol

\footnotetext{
${ }^{7}$ Mises (1949, p253) emphasizes this point, noting that "the various complementary factors of production cannot come together spontaneously. They need to be combined by the purposive efforts of [entrepreneurs]."

${ }^{8}$ Just as in the case of the Austrians, these contributions are not monolithic and scholars continue to debate their commensurability. For example, Coase (1937) focused primarily on the transaction costs associated with discovering market prices, whereas Williamson focused on the transaction costs stemming from the ex post appropriation of quasi rents (Bylund, forthcoming). Similarly, Williamson
} 
examined the role that society-wide institutions play in providing a framework for economic activity.

What unites these various strands of research is their focus on the role that institutions-the "humanly devised constraints that structure human interaction" - play in providing guideposts for human activity (North 1994, 360; Foss and Garzarelli 2007). Naturally, NIE's emphasis on how institutions structure incentives has had an important influence on the emerging economics of entrepreneurship. This focus on the guiding role of institutions for entrepreneurial actors was most famously noted by Baumol (1990), who argues that what differs between nations is not the supply of entrepreneurial talent but its allocation between productive (e.g., innovation), unproductive (e.g., rent seeking), and destructive (e.g., crime) activities. This allocation is determined by the relative payoffs that a society offers to such activities, and these payoffs are determined by the prevailing institutions (Baumol 1990; Boettke and Coyne 2003; Boettke and Piano 2016; Lucas and Fuller 2017; McCaffrey 2018). The primary conclusion is that entrepreneurship is a proximate cause of growth but institutions are the fundamental cause.

Baumol's classic 1990 paper has sparked a research program spanning both NIE and the "mainstream" entrepreneurship literature, with scholars deploying his framework to explain variation in the allocation of entrepreneurial activity across different nations - that is, why some nations have high rates of productive entrepreneurship while others have a larger share of unproductive activity (see, for instance, Coyne and Leeson 2004; Acs 2008; Aidis, Estrin, and Mickiewicz 2008; Sobel 2008; Bjørnskov and Foss 2008, 2016; Minniti 2008; Estrin et al. 2013; Stenholm et al. 2013). Furthermore, Baumol's work opened the door to extending entrepreneurship beyond the application to "productive activity" found in the works of Mises, Murray N. Rothbard, and Kirzner. At the same time, his framework stands to be enriched by further incorporation of subjectivism, process, and heterogeneity-a project that is advanced in the final section of this article. ${ }^{9}$

(1991) argued that Alchian and Demsetz (and, by extension, Cheung) were mistaken to downplay the hierarchical nature of the firm.

${ }^{9}$ McCaffrey (2018) notes that Baumol's account also overlooks uncertainty. 


\section{FINDING COMMON GROUND: SYNTHESIZING AUSTRIAN AND NIE SCHOLARSHIP}

\section{Institutional Environments}

What might a synthesis between the Austrian and NIE approach look like, specifically for furthering our understanding of the institutions-entrepreneurship nexus? To answer this question, one first must ask whether a synthesis is possible given the methodological differences between the two traditions. Certain strands of NIE are, indeed, deeply rooted in neoclassical economics, though it is generally seen as a relaxation of the stricter, more unrealistic assumptions of the neoclassical framework (Eggertsson 1990). Given that Austrians came to understand their unique identity in a sharp critique of core aspects of the emerging "neoclassical synthesis" during the socialist calculation debate, some may question whether such an integration is possible. ${ }^{10}$

To provide an overview of the Austrian assessment of NIE, we find it useful to follow Lance Edwin Davis and North (1971) in distinguishing between the "institutional environment" (society-wide rules that often arise spontaneously) and "institutional arrangements" (organizations that are usually the consequence of conscious design) ${ }^{11}$ Sometimes the distinction is described as being between "institutions" and "organizations," though admittedly, this line is not always easy to draw and some have challenged its existence altogether (see, for example, Cheung 1983).

Most Austrian criticism of NIE has focused on institutions, specifically Coase (1960), the locus classicus of what, under Stigler's

\footnotetext{
${ }^{10}$ For this reason, Palermo $(1999,277-78)$ argues that the Austrian and NIE traditions are "methodologically incompatible." NIE analysis dating back to Coase, he argues, is "explicitly developed within a neoclassical context." Its goal, according to Williamson (1985), is to explain all capitalist institutions by means of neoclassical tools and assumptions. Palermo therefore concludes that any attempt to reconcile the two traditions is "fundamentally misguided." We disagree strongly with this conclusion. It is worth noting, for instance, that both traditions have leveled critiques of Walrasian general equilibrium (Mises [1949] 1998; Kirzner 1997; North 1990; Barzel 1997).

${ }^{11}$ See Klein (2000) for a discussion of the distinction between the "institutional environment" and "institutional arrangements." This bears a striking semblance to Menger's distinction between "organic" and "pragmatic" institutions and Hayek's distinction between "cosmos" and "taxis," or planned versus spontaneous orders.
} 
influence, came to be known as the "Coase theorem." Austrian scholars advanced the idea that Coase was hostile to private property rights because his work can be read as suggesting that courts could reallocate rights on the basis of perceived willingness to pay when transaction costs are prohibitive (Block 1977, 1995; Rothbard 1979, 1982; Lewin 1982; Cordato 2004; Hülsmann 2004). Additionally, Austrians have argued that courts striving for Kaldor-Hicks efficiency encounter insuperable difficulties, namely that subjective costs cannot be aggregated and that assigning property rights encounters the calculation problem (Rizzo 1980; Lewin 1982; Stringham 2001). Given the "Posnerian" wealth maximization appropriation of Coase, such criticisms are justifiable, yet they may also explain why there has been more synthesis of Austrian ideas with NIE thinking on "organizations," rather than with "institutions" proper.

\section{Institutional Arrangements}

With a few notable exceptions, Austrian assessment of NIE contributions to organizations has been largely positive, beginning with Rothbard $([1962,1970] 2009)$ and including Nicolai J. Foss and Peter G. Klein (2012). The first noteworthy exception is Donald J. Boudreaux and Randall G. Holcombe (1989), who argue that the Coasian equilibrium framework is in tension with Austrian concerns for disequilibrium, and the second is Per Bylund (2014), who argues that Coase (1937) was attempting to provide justification for central planning. In contrast to these misgivings, Klein and Foss develop a theory of the firm-a subject that has been the primary NIE focus from its beginning-by incorporating Austrian insights into a framework that is grounded in Coase (1937; Klein 1999; Foss and Klein 2009, 2012). Foss and Klein (2012) see the Austrian emphasis on the entrepreneur as necessary for a robust theory of organization, arguing that entrepreneurs establish firms because the judgment they exercise is noncontractible and can thus only be expressed by forming a firm. ${ }^{12}$

\footnotetext{
${ }^{12}$ The emphasis on firm formation as a way for entrepreneurs to express the noncontractible element of the entrepreneurial function is also present in Manne's (2014) argument that entrepreneurship should be viewed as idea generation. It is also closely related to Barzel's $(1987,1997)$ notion that the residual claimant will be
} 
More recently, Ennio E. Piano and Louis Rouanet (2020) have argued that NIE scholars should incorporate insights bequeathed by the calculation debate. For their part, Austrian scholars ought to adopt a greater appreciation for the fact that private property rights are costly to establish and the corollary that, even in unhampered markets, not every asset will be privately owned due to the existence of transaction costs (Barzel 1997; Allen 2000; Piano and Rouanet 2020). ${ }^{13}$ Furthermore, Piano and Rouanet (2020) maintain that economic calculation over which property rights to establish can only occur in an institutional environment where some prices already exist and are free to arise. However, like Foss and Klein (2012), Piano and Rouanet (2020) develop their arguments in the context of organizational economics. Thus, one irony given the Austrians' Mengerian origins is that in the last thirty years Austrian work in "institutions and organizations" has tended to shift toward "institutional arrangements" and away from the "institutional environment." Yet, although the focus of their own argument is on organizational issues, Piano and Rouanet $(2020,16)$ hope their work "will build a bridge" between $\mathrm{NIE}$ and $\mathrm{AE}$ "with respect to...interventionism, entrepreneurship, and the economic analysis of law."

\section{A Path Forward}

A call for integration between the two traditions is supported both implicitly by NIE thinkers who have developed similar concepts to those in the Austrian tradition and explicitly by other scholars who have developed direct arguments in favor of synthesis. Implicit support for integration can be found in the mutual emphasis on (some form of) certain concepts ignored in the sterile general equilibrium approach. These concepts include a shared focus on (some form of) capital heterogeneity, exemplified in Williamson's "asset specificity" or Barzel's "attributes" (Lachmann [1956] 1978; Williamson, 1975, 1985; Barzel, 1982, 1997). Additional Austrian

the party whose contribution to production is costliest to measure. Note that the Kirznerian (1973) concept of "alertness" is also noncontractible.

${ }^{13}$ See Allen (2000) for why the costs of establishing and enforcing property rights are called "transaction costs," though this usage differs somewhat from the traditional neoclassical usage of the term. 
themes can be found in other aspects of Williamson's transaction cost economics, such as his frequent citations of Hayek on the nature of knowledge and adaptive learning (cf. Williamson 1985, 8). Similarly, North credits Hayek's work on how knowledge is generated and transmitted through time, specifically highlighting his idea of "collective knowledge," socially useful learning that is embodied in institutions as they evolve (North 1994, 364). ${ }^{14}$

Of course, drawing a direct line of influence between Austrian themes and the development of NIE thought is fraught with difficulty ${ }^{15}$ Still, these overlapping themes are worth noting, especially as explicit calls for integration have been sounded by scholars such as Richard N. Langlois $(1992,165)$, who was among the first to outline points of tangency between the two traditions. Like the NIE tradition, he argues, "the Austrian school of economics is and has been fundamentally concerned with the theory of social institutions."

This concern can be seen in Mises, who combined institutional analysis with a processual perspective by endogenizing institutions all while conducting institutional analysis using choice theoretic tools, methods that later became a staple of the NIE approach (Foss 1997). That Mises consistently rooted his institutional analysis in a market process approach is best exemplified in the socialist calculation debate. As he famously remarked, "the problem of economic calculation is of economic dynamics: it is no problem of economic statics" (Mises [1922] 1951, 139). Unlike the general equilibrium approach, Mises's analysis was not constrained by unrealistic assumptions of perfect knowledge or static equilibrium, and unlike old institutionalists, his analysis of institutions was not beholden to excessive historical details or atheoretical descriptions. The institutional analysis practiced by Mises therefore occupied a middle ground between formalism and old institutionalism (Lavoie 1985). ${ }^{16}$ As Foss $(1997,77)$ argues, Mises was "much more than a precursor" to NIE; he, in fact, managed to "blend institutional and

\footnotetext{
${ }^{14}$ Also note the heavy citations of Hayek by North in his work on institutional change (North 2005).

${ }^{15}$ See Bylund (2014) for one such attempt which draws this conclusion.

${ }^{16}$ Nonetheless, the institutional context was so front and center in Mises's analysis that Lange accused him of being an old institutionalist for his emphasis on the importance of private property (Boettke 2018).
} 
process analysis in a way that is still yet to be achieved by modern neo-institutionalists."

Hearkening back to one of the key Menger-Mises themes, more recent scholarship has renewed the call to explain the origins and evolution of institutions using the tools of economics (Leeson 2012). ${ }^{17}$ As Menger himself asked, "How can it be that institutions which serve the common welfare and are extremely significant for its development come into being without a common will directed toward establishing them?" $(1883,146)$. The following section shows that in the same way that Austrian insights have enriched NIE understanding of organizations, AE-NIE integration can also enhance our understanding of the institutions-entrepreneurship "black box."

\section{TOWARD AN INTEGRATED RESEARCH PROGRAM IN INSTITUTIONS AND ENTREPRENEURSHIP}

\section{Institutions and Subjectivism}

\section{Within-Institution Entrepreneurial Variation}

Although the literature inspired by Baumol (1990) can be described as an "empirical success story" in explaining variation in entrepreneurial activity between nations, it has generated fewer answers regarding what causes entrepreneurs within a given nation to respond to the same institutional rules in vastly different ways. As Christopher J. Boudreaux, Boris N. Nikolaev, and Peter Klein $(2019,1202)$ describe Baumol's approach, "incentives are clear and unambiguous and do not need to be interpreted." In other words, once institutions are exogenously determined, "Baumolian" entrepreneurs seemingly respond to the institutional environment by solving an objectively given maximization problem, that is, by directing their energies toward "productive," "unproductive," or "destructive" efforts (McCaffrey 2018). This approach renders the Baumolian "entrepreneur" little different from the "entrepreneur" (really, manager) of neoclassical

\footnotetext{
${ }^{17}$ This view is in stark contrast to Coase and Kirzner, who preferred to take institutions as exogenous with the task of the economist being to examine the economic activity occurring within those rules (Coase 1977; High 2009; Leeson 2012; Boettke 2014).
} 
producer theory, who "chooses" (really, reacts) to a given constellation of prices. The Baumol framework is certainly valuable for explaining differences in the overall allocation of entrepreneurial talent between nations, where the rules may vary considerably from one society to the next. To put it another way, this approach is helpful in generating an "average treatment effect" of the institutional environment. However, this framework has had less success explaining why entrepreneurs within the same country (and even producing similar products) often interpret and respond to the same rule in different ways.

Until recently, this question has received little attention. Preliminary attempts at addressing this puzzle can be seen in the emerging literature that examines the range of potential entrepreneurial responses to various institutional rules. This work expands on Baumol (1990) by demonstrating that entrepreneurial response, like entrepreneurial outcome, may also be divided into three broad categories: entrepreneurial actors may abide by, alter, or altogether evade the rules of the game (Coyne and Leeson 2004; Li, Feng, and Jiang 2006; Henrekson and Sanandaji 2011; Elert and Henrekson 2016). An abiding strategy refers to entrepreneurial action that complies with the institutional status quo; an altering strategy occurs when entrepreneurs lobby rule makers for change; an evasive strategy seeks to circumvent the rules entirely (Henrekson and Sanandaji 2011; Elert and Henrekson 2017).

Although this taxonomy of entrepreneurial response to the institutional context has expanded Baumol's taxonomy, additional research ought to explore the factors that influence an entrepreneur's decision to abide, alter, or evade. Perhaps one reason why NIE scholars have not made more progress on this question is because the standard neoclassical toolkit has limitations that render it difficult to open this black box. For instance, many, though certainly not all, NIE scholars have treated the formal institutional rules that govern a society as not only objectively given to entrepreneurs, but also uniformly interpreted by them. ${ }^{18}$

${ }^{18}$ Leeson's (2012) distinction between the "Coasian" and "Posnerian" approach to institutions is apropos. The former approach takes institutions as both exogenous and beyond the reach of economics to explain. Within economics, Allen (2011) and Leeson (2017) are excellent examples of endogenizing a wide range of social 
Incorporating Austrian insights may shed light on the question of why entrepreneurs adopt different strategies by further "disaggregating" the relationship between entrepreneurship and institutions. Entrepreneurs possess not only different values and preferences, but also different knowledge and expectations of the future. Institutions are therefore perceived as they are filtered through the subjective lens of each economic actor. This implies that all entrepreneurs face differing and subjectively determined costs and benefits associated with alternative ways of interacting with the institutional environment. They also possess different propensities for noticing perceived profit opportunities.

Imagine two rock climbers attempting to surmount the same wall at a rock-climbing gym. In this case, the constraint of geography is undoubtedly "real," but the perception of it must still be filtered through the climbers' minds. An unnuanced reading of Baumol (1990) may tempt some economists to assume that each climber's (i.e., entrepreneur's) approach to this challenge will be identical because the challenge they face is identical-they are both trying to summit the same (objective) rock formation. But the "institutional entrepreneurship" literature has highlighted that such an assumption is likely misleading (Henrekson and Sanandaji 2011; Elert and Henrekson 2020).

Consider the following reasons for why one of the climbers may attempt a different approach to ascending the rock wall. Suppose one climber has already scaled that particular wall or was able to learn from observing the successes and failures of other climbers (in other words, he is more experienced). To explore another possibility, suppose a climber is being radioed by his friend who works at the gym and who is able to describe a pass that remains hidden to the climbers from their current vantage point. In either of these cases, both climbers seemingly face the same objective constraint. Yet one has unique (i.e., subjective) knowledge about a superior route that may not be visible to the other climber from their current vantage point. In Hayek's words, one climber's superior knowledge of the "particular circumstances of time and place" may lead him to adopt a different route.

institutions to the choices of individuals who solve problem situations by devising new institutional constraints. 
The analogy is somewhat crude. Nevertheless, it conveys the point about how two actors may adopt different strategies based on their subjective perceptions of what is seemingly the same objective constraint. In this example, one climber not only perceives the costs and benefits of a route differently than his counterpart, but he may also be aware of a route that is hidden to his friend. This analogy suggests two important avenues of research. The first possibility, that each climber simply assesses the costs and benefits of alternative routes differently, demonstrates that "judgment" is required in all contexts (Boudreaux, Nikolaev, and Klein 2019). A subjectivist perspective emphasizes that, even when placed in identical environments with identical knowledge, not all entrepreneurs will form the same conjectures about the future, perhaps due to differing sociocognitive traits or other factors that lie beyond the realm of economics and in the domain of thymology (Boudreaux, Nikolaev, and Klein 2019).

The second possibility, that entrepreneurs may possess differential knowledge, suggests that more remains to be understood about the use of institutional knowledge in society. Austrians are known for their concern with the epistemic properties of institutions, but to the extent that they have developed this research agenda, they have tended to focus on how different institutional environments influence entrepreneurial learning in market settings, such as how alternative contract regimes facilitate or impede the market process (Wonnell 1985). Although an important line of inquiry, understanding how market actors acquire knowledge of their institutional environment is another promising topic.

Knowledge of institutions includes awareness of "institutional contradictions," such as when the costs of regulation are prohibitively high. Levying noncompliance fines on AirBnB hosts in New York City is one example, as the costs of monitoring by regulators are prohibitive in this case, allowing for a profitable opening (Elert and Henrekson 2016). It also includes knowledge of the institutional players themselves, of their ideologies, experiences, and what they can do for market-based entrepreneurs in particular contexts. Unsurprisingly, the importance of these considerations grows when the agency in question wields discretionary powers (Newman 2019). 
A way for Austrians to build on these insights is in developing a concept that parallels the so-called knowledge filter of mainstream entrepreneurship literature. The knowledge filter either facilitates or impedes the diffusion of technical knowledge (Acs et al. 2004). Factors such as the university innovation system and the structure of intellectual property rights comprise the "filter," determining how much technological knowledge disseminates to others who then deploy it in new entrepreneurial ventures. Yet, in many circumstances, knowledge pertaining to the institutional environment can be just as important for profit seekers as is technological know-how. This is particularly true in environments with a large divergence between de facto and de jure rules.

A concrete example of the importance of institutional knowledge is the informal blat system of graft that enabled superior navigation of the commercial realm during the post-Soviet transition years (Ledeneva 2009). Being "embedded" in this informal and corrupt network proved a key determinant of entrepreneurial success in this environment (Aidis, Estrin, and Mickiewicz 2008). Social embeddedness was critical for understanding which rules would be enforced and which officials were susceptible to bribery. Given their historic strength in examining "organic" institutions, Austrians might turn their attention to exploring the emergence and roles played by such "meso-level" institutions as informal or black market networks (Kim, Wennberg, and Croidieu 2016). "Meso" institutions, the informal network of ties that exists "between" formal institutions and spontaneously arising norms, may thus enable some entrepreneurial action even in contexts subject to regime uncertainty, but the extent of it is not yet well understood (cf. Bylund and McCaffrey 2017).

More obvious in transition economies, the divergence between de facto and de jure is important in less corrupt environments too, suggesting a list of questions that Austrians are poised to address (Colombatto 2003). Is institutional knowledge diffused through meso-level networks? Are such networks an emergent response to weak formal rules? Are entrepreneurs without political or informal connections more likely to engage in evasive entrepreneurship due to their unfamiliarity with the rules and rule makers? Most importantly, can attention to institutional knowledge help scholars understand within-country entrepreneurial variation and therefore 
within-country economic development? To provide concrete answers for this variation, scholars should conduct intensive research that takes subjectivism seriously by allowing for a looser link between "given" institutions and entrepreneurial response.

\section{Economic vs. Legal Property Rights}

Applying subjectivism to institutions helps to avoid the pitfalls in the seemingly harmless assumption that there is no ambiguity, contradictions, or gaps in a society's formal rules, nor in the interstices formed by imperfect alignment between formal and informal rules (Boettke, Coyne, and Leeson 2008). One notable NIE scholar sidesteps this pitfall by offering what might be considered an idiosyncratic definition of property rights but one which bears marked similarities to the way that Mises understood property rights. Barzel $(1994,394)$ defines a property right as "an individual's net valuation, in expected terms, of the ability to directly consume the services of an asset, or to consume it indirectly through exchange." He adds: "A key word is ability: The definition is concerned not with what people are legally entitled to do but with what they believe they can do," (ibid. 1994, 394). Meanwhile, Mises ([1949] 1998, 678) defines a property right as "full control of the services that can be derived from a good." Kirsten Foss and Nicolai J. Foss (2002) argue that Barzel's conception of a property right, by placing the emphasis on individuals' beliefs, is highly consistent with the subjectivism of the Austrian tradition. ${ }^{19}$

In his landmark 1997 text, Barzel describes how this definition leads naturally to a distinction between "economic" and "legal" property rights, where the former are what a person can actually do (de facto), while the latter are what the legal apparatus, usually the state, permits (de jure). Despite the subtle differences in these definitions of property rights, this foregoing distinction can also be found in Mises ([1922] 1951), who emphasizes the distinction

\footnotetext{
${ }^{19}$ Both Barzel $(1994,1997)$ and Mises (1949) identify control as the locus of ownership. However, Barzel's definition is arguably rooted in "expected utility," a framework which Mises rejected for its failure to incorporate true uncertainty. Substituting the word belief for expectations, as the second part of Barzel's definition does, certainly bring the two conceptions closer together.
} 
between "having" something and legal ownership, stating: "Economically, however, the natural having alone is relevant, and the economic significance of the legal should have lies only in the support it lends to the acquisition, the maintenance, and the regaining of the natural having," (p. 37, emphasis in original). We concur with Foss and Foss (2002) and Piano and Rouanet (2020) that this Mises-Barzel distinction is more than mere theoretical curiosity. Indeed, it has already been deployed in Austrian work on organizational economics. In similar fashion, incorporating this subjectivist understanding of property rights into the analysis of society-wide institutions also has important implications for how scholars might conduct research at the institutions-entrepreneurship interface.

Take the work on legal origins by Andrei Shleifer and various colleagues, which is among the most cited economics research of the last three decades. This research seeks to illuminate the influence of legal institutions, such as shareholder rights, on commercial activity and economic growth. ${ }^{20}$ Some scholars have even argued that this body of work represents a "missed opportunity" for those in the Austrian tradition because it essentially turns Hayek's arguments on law into an empirically testable research agenda (Subrick and Beaulier 2004). ${ }^{21}$

The work of Shleifer (and coauthors) might be faulted for relying too heavily on de facto measures of institutional quality. Though having missed the opportunity of generating this literature, Austrians still have the opportunity of sidestepping these criticisms of overreliance on de facto measures by embracing the MisesBarzel definition of property rights in their empirical work. To do this, scholars might conduct surveys of entrepreneurs to ascertain their perceptions - their "expectations," in Barzel's terminology—of the institutional environment. Such an approach is particularly important because Austrian work in the theory of institutions has

${ }^{20}$ See Glaeser and Shleifer (2002) and La Porta, Lopez-de-Silanes, and Shleifer (2008) for overviews of this literature.

${ }^{21}$ Arguably, another missed opportunity for Austrians is the "new economics of management" literature, which examines the connection between labor regulations and management practices worldwide (Bloom and Van Reenen 2010; Bloom et al. 2019). It can be interpreted as empirical support for Mises's argument that "bureaucratization" of business is a result of government intervention (Mises 1944; Klein 1999, 36). 
emphasized that formal institutions only "stick" when they exhibit strong correspondence with the underlying, informal norms of a society (Boettke, Coyne, and Leeson 2008; Williamson 2009). Some preliminary work in this direction has already been conducted by mainstream scholars, such as Simon Johnson, John McMillan, and Christopher Woodruff (2002), who survey entrepreneurs about the institutional environment in transition economies and reject the hypothesis that liquidity constraints are responsible for low reinvestment rates. ${ }^{22}$ Public predation is the culprit.

This subjectivist approach to institutions accounts for "what people think and believe" (Hayek 1943), their expectations about the "institutional environment," and thus helps to open the "black box" of de facto measures. By incorporating the Misesian (and NIE) distinction between "legal" and "economic" property rights, scholars can better build on the empirical forays into the institutions-entrepreneurship relationship (Bowen and DeClerq 2008; Bjørnskov and Foss 2008; Sobel 2008). A subjectivist approach naturally suggests that scholars investigate the moderating and mediating interactions of formal and informal institutions (which may be measured via survey) for entrepreneurial outcomes. How important are "productive" formal institutions if the underlying informal institutions are sound (and vice versa)? This approach also suggests the development and use of more fine-grained measures of the informal institutional environment, such as asking entrepreneurs questions about their commercial interactions with others, as a substitute for the typical reliance on society-wide measures of "trust."

\section{Institutions and Process}

\section{Intended Institutional Change}

NIE scholars have criticized general equilibrium models that assume perfect information and zero transaction costs and are thus poorly suited to explain why and how economies and their institutions evolve. Indeed, as has been widely noted, such models

\footnotetext{
${ }^{22}$ Shleifer and Fyre (1997) have employed a survey method to investigate entrepreneurs' perceptions of government quality in transition economies.
} 
are ill equipped to explain the very existence of institutions at all. In his Nobel Prize address, North $(1994,359)$ pinpointed these shortcomings. "Neoclassical theory," he argued, "is simply an inappropriate tool to analyze and prescribe policies that will induce development." North even acknowledges that one of the goals of economic historians working in the NIE tradition is to "not only shed new light on the economic past, but also to contribute to economic theory by providing an analytical framework that will enable us to understand economic change" (359). He concluded that economists studying institutions need to shift from general equilibrium models that posit a "static and frictionless world" and toward a dynamic framework "capable of increasing our understanding of the historical evolution of economies over time" —one that takes seriously how "the learning process of human beings shapes the way institutions evolve" (360).

North's plea for scholars of institutions to discard static equilibrium models in favor of a dynamic framework invites those who embrace the compositive method adopted by Austrians dating back to Menger in his pioneering analysis of the origins of money. As Langlois $(1992,170)$ notes, this causal-genetic approach explains how social institutions evolve over time by "tracing out a sequence of events rather than merely constructing the conditions for an equilibrium." This approach to institutional analysis relies on "invisible hand explanations" built on the foundations of subjectivism and methodological individualism, allowing it to explain social phenomena as emerging in bottom-up fashion from the purposive actions of individuals.

For Austrians, entrepreneurial action is the driving force behind this institutional evolution. Identifying the entrepreneur as the catalyst of change has allowed Austrians to avoid the puzzle posed by Kenneth J. Arrow (1959), who pondered who is responsible for changing prices in a general equilibrium world. However, similar quandaries may be generated by viewing institutions as merely exogenous constraints to which entrepreneurs helplessly react. Adopting such a perspective would import a version of the bloodless price-taking "entrepreneur" (really, producer) who populates the static world of general equilibrium models.

By contrast, incorporating an entrepreneurial agent who drives institutional change is important, because, by NIE scholars' own 
admission, institutional dynamics are largely treated as a "black box." Perhaps nothing better illustrates this claim than the Demsetz (1967) analysis of the transition from common to private property. In this landmark account, changes in the relative costs and benefits of private property are translated seamlessly into a change in the property regime. To paraphrase Garrison (1995), "it's 'costs and benefits' the whole way down." Because of their focus on process over equilibrium states and their emphasis on entrepreneurs as catalysts of change, Austrians are well positioned to contribute to theories of institutional evolution (Leeson and Suarez 2015). To be sure, repeating the phrase "entrepreneurs matter" as an explanation for institutional change is no better than repeating the mantra that "institutions matter" to explain economic outcomes. What is needed are "entrepreneurial microfoundations" that illuminate the mechanisms by which entrepreneurs spur institutional change.

Jack High (2009) offers one such account in which new institutions emerge as a result of entrepreneurial actors attempting to realize "gains" (not necessarily money profits). In this story, an alert entrepreneurial actor introduces an "institutional innovation," such as indirect exchange. The second step in this sequence also requires an act of entrepreneurship. As High argues, a second adopter of the new institutional innovation must recognize it and then decide upon adoption. He notes: "Observation requires alertness of the kind emphasized by Kirzner; deciding whether or not to adopt the new practice requires judgment in the face of uncertainty, as emphasized by Mises" (High 2009, 8). That economic activity takes place in close social proximity provides opportunity for "observation and communication" (8). People are convinced to adopt the institution via "imitation" (emphasized by Menger) and persuasion (not explicit in Menger's story). High deploys this framework to examine the emergence of money, the division of labor, accounting, and the transition from common to private property.

High's analysis is fruitful because it raises a host of research questions that Austrians are positioned to integrate with existing thinking on institutional change. For example, appealing to Williamson's (2000) hierarchical approach to analyzing institutional structures, Bylund and McCaffrey (2017) describe how entrepreneurs shift activity between institutional "levels" when government policy reduces the profitability of acting on one level 
relative to others. The highest level in Williamson's hierarchyL1 - consists of informal norms and rules (i.e., religious beliefs, customs, etc.), and Williamson contends that L1 changes only slowly, usually on the scale of a century to a millennium. Bylund and McCaffrey $(2017,461,465)$ likewise argue that "entrepreneurs can experience extreme difficulty when trying to act in L1," because the "social embeddedness level (L1) is far less amenable to direct and frequent change."

However, Robert C. Ellickson (2001) advances a theory of "norm entrepreneurs," while North (1990) sketches the concept of "ideological entrepreneurs," developed further by Virgil Henry Storr (2011). These change agents aim at shifting society's slowest moving, most spontaneous rules. Austrians will appreciate the general thrust of Ellickson's theorizing because of his explicit emphasis on purposive action but will also find ways to improve and extend his analysis. For example, Ellickson's (2001) entrepreneurial actor is someone who simply adjusts conditions to changes in the relative prices imposed by changing constraints, rather than acting as an agent who might also introduce relative price changes. Secondly, Ellickson's analysis focuses on individuals who introduce norm changes to gain social applause, but what of entrepreneurs who introduce "L1" changes in anticipation of money profits because a combination of government intervention and existing norms would otherwise curtail their ability to do so? To what extent, and when, do market entrepreneurs undertake "norm entrepreneurship" as a means of augmenting their profitability? Because such pursuits have society-wide implications, are they often pursued collectively by profit seekers, and if so, what institutional innovations do entrepreneurs implement to monitor and enforce contribution to this "public good" (Dorobantu, Kaul, and Zelner 2017)?

Regardless of one's stance on the alterability of L1 rules, research on intentional institutional change by entrepreneurs, even that occurring at a lower level of Williamson's hierarchy, raises a host of questions that Austrians are poised to address. The first question has to do with the nature of the feedback guiding an actor like High's "institutional entrepreneur" (our term, not his). Entrepreneurial activity within the context of private property yields money prices, profits, and losses, which facilitate monetary calculation. Does entrepreneurial activity over the rules of the game also generate high-quality feedback (Boettke 
and Coyne 2009, 192-95)? What substitutes for money profits and losses when entrepreneurship is occurring over the institutional prerequisites to profit-and-loss accounting?

Second, Austrians might deploy this step-by-step approach to better understand entrepreneurial solutions to the "grand challenges" that societies face, such as the private provision of goods with "publicness" characteristics, the prevention of war, the mitigation of diseases, development, immigration, aging populations, or the supplying of "missing" institutions. ${ }^{23}$ On this last topic, Boettke and Peter T. Leeson (2009) show that, especially for the underdeveloped world, the traditional view of entrepreneurs acting within a given institutional framework is highly deficient. ${ }^{24}$ In underdeveloped nations, formal institutions of property and contract enforcement are often severely lacking (Rajan 2004). Because there is gain to be had in supplying this missing framework, entrepreneurs work to directly supply these institutions. Once again, though, questions of feedback arise. There are also questions about the antecedents to success; for instance, how weak must public governance be for entrepreneurs to successfully provide and enforce the overarching legal framework?

Third, some Austrians have argued that market entrepreneurship yields a "multiplier effect" whereby entrepreneurial action generates subsequent profit opportunities (Holcombe 1998; Coyne, Sobel, and Dove 2010). ${ }^{25}$ The mechanism by which this occurs has been spelled out for market entrepreneurship within a set of institutional rules. Austrians might contribute to the entrepreneurship literature by examining whether similar mechanisms are at work in the case of institutional entrepreneurship. Lastly, the High (2009) account is focused on institutions which arise out of purely voluntary interactions, so

\footnotetext{
${ }^{23}$ See George et al. (2016) for a discussion of how management scholars are tackling "grand challenges."

${ }^{24}$ This point is also applicable to many "pockets" of underdeveloped institutions in the developed world. See, for example, David Skarbek (2014) on prison gang governance.

${ }^{25}$ Hülsmann (1999) disputes this mechanism by arguing that it is impossible to know whether an act of entrepreneurship, on net, creates additional opportunities for subsequent entrepreneurship. He also objects to what he sees as a passive conception of entrepreneurship in Holcombe's argument. Holcombe (1999) responds by granting that it is impossible to know the counterfactual pertaining to additional acts of entrepreneurship. However, he makes the subtler point that the new opportunities are better suited to satisfying consumer preferences.
} 
what must be modified to understand the evolution of institutions, such as slavery, which are undergirded by violent actions?

\section{Unintended Institutional Change}

Although the High (2009) analysis suggests that institutional change results from an entrepreneurial actor who explicitly attempts to alter the existing institutional framework, this is not always the case. Entrepreneurs may (unintentionally) reinforce the status quo through abiding entrepreneurship or (unintentionally) alter that status quo through evasive entrepreneurship, even when institutional alteration is not their explicit aim (Elert and Henrekson 2016, 2020). As an illustration, David S. Lucas and Caleb S. Fuller (2018) explore the "market-making" activities of entrepreneurs in the face of interventionist policies. Certain interventions-such as bounties- "commodify" products which did not previously possess "goods-character" in the Mengerian sense. For example, they describe how entrepreneurs increased the supply of pests for which public authorities had set a bounty. In the cases they examine, entrepreneurship undermined the stated rationale of the intervention, leading to its eventual repeal. Institutional alteration was the outcome, though not the intention, of the market-making entrepreneurs who responded to the intervention.

Similarly, Niklas Elert and Magnus Henrekson (2016) describe how evasive entrepreneurship may also foster formal institutional change, despite that not being any entrepreneurial actor's explicit intent. Consider the following examples that they provide: the success of Chinese farmers' (illegal) experiments with private property subsequently undergirded arguments that facilitated China's move in the 1990s toward agricultural privatization; a private network of TV stations in Italy undermined the public telecommunications monopolies; and the rise of Uber caused taxi monopolies to implement "surge pricing" to compete with their new rivals.

These examples are preliminary attempts at opening the "black box" that conceals the mechanisms by which entrepreneurs generate institutional change; much more work is yet to be done. For example, is institutional change usually a result of intentional action by entrepreneurs, as in the case of "altering" activity (Elert and Henrekson 
2017), or is institutional evolution more commonly an unintentional by-product of entrepreneurial behavior, as in the cases described by Lucas and Fuller (2018)? Furthermore, evasive entrepreneurship clearly does not always precipitate formal institutional change. Uber's evasive activity vis-a-vis taxicab monopolies has eroded the latter's rents and forced pricing adjustments, but has not yet generated wholesale repudiation of transportation licensure.

Additionally, when evasive entrepreneurship does generate institutional change, the mechanisms driving that change are also largely unclear. For example, some instances of evasive entrepreneurship might render a public monopoly unprofitable, whereas others might bring public pressure to bear on existing institutions. In yet other cases, evasive entrepreneurship might simply serve as the template for public entrepreneurs attempting to implement reforms (Klein et al. 2010). ${ }^{26}$ Future research might explore the conditions under which evasive entrepreneurship tends to result in explicit institutional change while also better enumerating the mechanisms by which evasive entrepreneurial activity translates into institutional change.

\section{Institutions and Heterogeneous Capital}

Another hallmark of the Austrian tradition is its emphasis on capital as a network of interconnected, heterogeneous, and multispecific produced factors of production (Mises [1949] 1998; Lachmann [1956] 1978; Rothbard [1962, 1970] 2009; Kirzner 1966; Lewin 1998; Powell 2010; Burns 2018a). This stands in marked contrast to mainstream economic theorizing going back to Knight that treats capital as an undifferentiated blob of "shmoo" (Foss and Klein 2012, 105-07). Historically, the Austrian emphasis on capital heterogeneity has played an important role in macroeconomic or systemwide analyses, specifically trade cycles and the calculation debate. ${ }^{27}$ Capital heterogeneity featured prominently in the calculation debate, because if capital goods are costlessly interchangeable between production processes, the calculation problem becomes

\footnotetext{
${ }^{26}$ Cf. DiLorenzo (1988).

${ }^{27}$ Famously, it was Mises's emphasis on capital heterogeneity that led Frank Knight to pan Human Action
} 
much less severe even if not altogether irrelevant. ${ }^{28}$ It was also a centerpiece of early twentieth-century Austrian development of the trade cycle. This emphasis continues to this day, particularly as mainstream macro continues to deploy homogenizing assumptions about capital that obscure the ways that monetary policy generates booms and busts (Garrison 2000; Boettke and Piano 2019).

Given these historical foci, there is promise in examining the more strictly microeconomic implications of capital heterogeneity, especially those which pertain to institutions and entrepreneurship. In fact, several NIE scholars have also relaxed the capital homogeneity assumption to generate explanations of microeconomic phenomena. Williamson $(1975,1985)$, for instance, leans heavily on his notion of "asset specificity" - investments that have transaction-specific characteristics which reduce their value in alternative lines of production - to explain the wide array of institutional arrangements that firms devise, including "arm's length" contracts, vertical integration, and in-between hybrids. ${ }^{29}$ Another notable example is Barzel's $(1982,1997,2005)$ contention that capital assets are best characterized as bundles of "attributes," arguing that it is costly to completely and perfectly define property rights over each of an asset's attributes. He deploys these insights to explain why some attributes are left in the "public domain" (that is, are not privately owned) and also reexamines classic questions pertaining to the widespread variation in contractual forms.

Arguably, Barzel's notion of asset attributes is inherently more amenable to Austrian theorizing - it maps almost perfectly onto Lachmann's ([1956] 1978, 2-5) notion of multiple specificity-than is Williamson's concept of asset specificity, since the latter has specific users rather than specific uses in mind (Klein 2009). There

\footnotetext{
${ }^{28}$ There is ambivalence on whether perfect capital homogeneity would eliminate calculation problems. Horwitz $(1998,438)$ states: "If all capital goods are perfectly substitutable, no calculation is necessary....If all capital goods are perfectly specific, such choices are also not necessary." Foss (2012, 152-53) argues: "In fact, even if capital were homogeneous, there would still be calculation problems left (how much homogeneous capital to devote to production now versus later)." Foss and Klein (2012) cite Mises ([1949] 1998) saying that only "trivial calculation" problems exist in a world of "shmoo" capital.

${ }^{29}$ For Williamson, the other determinants of contractual form include transaction frequency and uncertainty, but he has argued that asset specificity is the most determining.
} 
are still ways, however, that Austrian concepts can further enrich and build on the framework provided by the attributes concept. To begin, Barzel's conception of heterogeneous goods implicitly assumes that all attributes have been discovered but that it is prohibitively costly to define property rights over each of them (Foss and Foss 2002). Kirzner (1966), however, argues that a capital good's multispecific uses ("attributes" in the Barzelian terminology) must be subjectively perceived by entrepreneurial actors who integrate them into a production plan. This point has been used to explain firm and asset ownership (Foss and Foss 2001), but we see room for more work that links entrepreneurs' discovery of valuable assets to society-wide institutions.

Clearly, not all institutional environments are equally conducive to the perception of asset attributes nor how they can be profitably deployed. Kirzner (1985), for instance, recognizes that government intervention alters the market process by stifling some discoveries and in generating superfluous avenues for profit making (i.e., rent seeking). This logic might be extended to explore how the institutional environment facilitates or impedes discovery of asset attributes under an entrepreneur's control. Alternatively, interventionist institutions may generate discovery of attributes which prove useful in evasive entrepreneurship but which may not have been discovered absent the intervention.

Cell phones provide a useful illustration of both cases. As Burns (2018b) documents, permissive regulatory environments in Sub-Saharan Africa facilitated the discovery of cell phone attributes which would allow them to serve as a platform for a banking system. Yet a laissez-faire environment is not the only context under which valuable attributes may be discovered. For example, that smartphones could coordinate a ride-sharing platform was only discovered when it was due to the existence of interventionist institutions. Of course, to note this is to say nothing of the welfare implications in either case. More research is needed to understand the conditions which facilitate the first or second outcome.

Other research demonstrates that the "elasticity of substitution" between capital goods is endogenous to the institutional environment (Bjørnskov and Foss 2016). Such reasoning naturally generates a host of follow-up questions. How do entrepreneurs 
structure contracts (e.g., duration, asset ownership, etc.) to protect their assets' most valuable attributes in the face of known interventionist institutions? Furthermore, how do contractual arrangements change when entrepreneurs confront institutional uncertainty regarding intervention (Higgs 1997; Terrell 2013; Baker, Bloom, and Davis 2016; Bylund and McCaffrey 2017)? Relatedly, do entrepreneurs who command highly specialized assets devote more resources to the political process to better secure their rents? Entrepreneurs in these contexts are presumably more "exposed" by the thin markets in which they operate, suggesting higher payoffs from political activity.

\section{CONCLUSION}

The Austrian and new institutional economics traditions both place an emphasis on the vital role that institutions play in guiding human affairs. They also acknowledge the central role of the entrepreneur in the economy. This article contributes to prior efforts at bridging the gap between the two traditions by identifying some unrealized gains from trade: a more thoroughgoing subjectivism, an emphasis on process, and an incorporation of capital heterogeneity will open new areas of inquiry for the project of examining the relationship between institutions and entrepreneurship.

Scholars might shrink remaining gaps between AE and NIE by viewing transaction costs as the by-product of choice rather than objective, unalterable, exogenously given constraints (Robbins 1934; Buchanan 1969; DiLorenzo 1990). Indeed, North's thinking evolved in this very direction over the course of his career (Candela, forthcoming). One implication is that scholars might turn their attention to entrepreneurial activity that is aimed explicitly at reducing transaction costs (Candela and Geloso 2019). Transaction costs, the costs of establishing property rights (Allen 2000), may arise out of either private opportunism or public predation. Although Austrian economics has emphasized the rivalrous striving by entrepreneurs to satisfy consumer preferences by discovering least-cost production techniques (Hayek 1948), these insights can be profitably extended to entrepreneurial action whose aim is to reduce transaction costs specifically. This research program will identify a host of institutional constraints 
that are devised to address the problem situations that consumers and producers confront. It will also reveal the entrepreneur as not only the driving force of change within a given institutional context, but also as the driver of institutional change itself. As has been argued, simply positing the existence of a change agent is insufficient. The antecedents, mechanisms, and feedback for institutional change should be elaborated.

This article is not intended to provide a comprehensive overview of all the ways that the Austrian and NIE traditions can learn from one another. Nevertheless, the hope is that this preliminary theoretical sketch will open up profitable new avenues for institutional research that incorporate important insights from both traditions. If this goal has been achieved, future scholarship on institutions and entrepreneurship will be grounded in Austrian insights and yield fruitful empirical findings.

\section{REFERENCES}

Acs, Zoltan J., David B. Audretsch, Pontus Braunerhjelm, and Bo Carlsson. 2004. "The Missing Link: The Knowledge Filter and Entrepreneurship in Endogenous Growth." Centre for Economic Policy Research (CEPR) Discussion Paper, London.

Acs, Zoltan J., Sameeksha Desai, and Jolanda Hessels. 2008. "Entrepreneurship, Economic Development and Institutions." Small Business Economics 31, no. 3: 219-34.

Aidis, Ruta, Saul Estrin, and Tomasz Mickiewicz. 2008. "Institutions and Entrepreneurship Development in Russia: A Comparative Perspective." Journal of Business Venturing 23, no. 6: 656-72.

Alchian, Armen A., and Harold Demsetz. 1972. "Production, Information Costs, and Economic Organization." American Economic Review 62, no. 5: 777-95.

Allen, Douglas W. 2000. "Transaction Costs." In Encyclopedia of Law and Economics, ed. Boudewijn Bouckaert and Gerrit De Geest. Edward Elgar.

- 2011. The Institutional Revolution: Measurement and the Economic Emergence of the Modern World. Chicago: University of Chicago Press. 
Alvarez, Sharon A., and Jay B. Barney. 2007. "Discovery and Creation: Alternative Theories of Entrepreneurial Action." Strategic Entrepreneurship Journal 1, no. 1-2: 11-26.

Arrow, Kenneth J. 1959. “Toward a Theory of Price Adjustment." Pp. 41-51 in The Allocation of Economic Resources, by Moses Abramovitz. Stanford, Calif.: Stanford University Press.

Baker, Scott R., Nicholas Bloom, and Steven J. Davis. 2016. "Measuring Economic Policy Uncertainty." Quarterly Journal of Economics 131, no. 4: 1593-1636.

Barzel, Yoram. 1982. "Measurement Cost and the Organization of Markets." Journal of Law and Economics 25, no. 1: 27-48.

— . 1987. "The Entrepreneur's Reward for Self-Policing." Economic Inquiry 25, no. 1: 103-16.

_ . 1994. "The Capture of Wealth by Monopolists and the Protection of Property Rights." International Review of Law and Economics 14, no. 4: 393-409.

- 1997. Economic Analysis of Property Rights. 2d ed. New York: Cambridge University Press.

- 2005. "Organizational Forms and Measurement Costs." Journal of Institutional and Theoretical Economics 161, no. 3: 357-73.

Baumol, William J. 1990. “Entrepreneurship: Productive, Unproductive, and Destructive." Journal of Political Economy 98, no. 5: 893-921.

Becker, Gary S. 1968. "Crime and Punishment: An Economic Approach." Journal of Political Economy 76, no. 5: 169-217.

Bjørnskov, Christian, and Nicolai J. Foss. 2016. "Institutions, Entrepreneurship, and Economic Growth: What Do We Know and What Do We Still Need to Know?" Academy of Management Perspectives 30, no. 3: 292-315.

—. 2008. "Economic Freedom and Entrepreneurial Activity: Some Cross-country Evidence." Public Choice 131, no. 1: 307-28.

Block, Walter E. 1977. "Coase and Demsetz on Private Property Rights." Journal of Libertarian Studies 1, no. 2: 111-15. 
. 1995. "Ethics, Efficiency, Coasian Property Rights, and Psychic Income:

A Reply to Demsetz." Review of Austrian Economics 8, no. 2: 61-125.

Bloom, Nicholas, Erik Brynjolfsson, Lucia Foster, Ron Jarmin, Megha Patnaik, Itay Saporta-Eksten, and John Van Reenen. 2019. "What Drives Differences in Management Practices?" American Economic Review 109, no. 5: 1648-83.

Bloom, Nicholas, and John Van Reenen. 2010. "Why Do Management Practices Differ across Firms and Countries?" Journal of Economic Perspectives 24, no. 1: 203-24.

Bobbins, Lionel. 1934. "Remarks upon Certain Aspects of the Theory of Costs." Economic Journal 44, no. 173: 1-18.

Boettke, Peter J. 1989. "Evolution and Economics: Austrians as Institutionalists." Research in the History of Economic Thought and Methodology 6: 73-89.

_ 1998. "Economic Calculation: The Austrian Contribution to Political Economy." Advances in Austrian Economics 5: 131-58.

—. 2014. “Entrepreneurship, and the Entrepreneurial Market Process: Israel M. Kirzner and the Two Levels of Analysis in Spontaneous Order Studies." Review of Austrian Economics 27, no. 3: 233-47.

—_ 2018 "Economics and Public Administration." Southern Economic Journal 84, no. 4: 938-59.

Boettke, Peter J., and Christopher J. Coyne. 2003. "Entrepreneurship and Development: Cause or Consequence?" Advances in Austrian Economics 6, no. 1: 67-87.

—_ 2009. "Context Matters: Institutions and Entrepreneurship." Foundations and Trends in Entrepreneurship 5, no. 3: 135-209.

Boettke, Peter J., Christopher J. Coyne, and Peter T. Leeson. 2008. "Institutional Stickiness and the New Development Economics." American Journal of Economics and Sociology 67, no. 2: 331-58.

Boettke, Peter J., Christopher J. Coyne, and Patrick Newman. 2016. "The History of a Tradition: Austrian Economics from 1871 to 2016." Research in the History of Economic Thought and Methodology 34, no. 1: 199-243.

Boettke, Peter J., and Ennio Emanuele Piano. 2016. "Baumol's Productive and Unproductive Entrepreneurship after 25 Years." Journal of Entrepreneurship and Public Policy 5, no. 2: 16-11. 
— . 2019. “Capital, Calculation, and Coordination." Pp. 9-24 in Including a Symposium on Ludwig Lachmann, ed. Luca Fiorito, Scott Scheall, and Carlos Eduardo Suprinyak. Vol. 37B of Research in the History of Economic Thought and Methodology. Bingley, U.K.: Emerald Publishing.

Boudreaux, Donald J., and Randall G. Holcombe. 1989. “The Coasian and Knightian Theories of the Firm." Managerial and Decision Economics 10, no. 2: $147-54$.

Boudreaux, Christopher J., Boris N. Nikolaev, and Peter Klein. 2019. "Socio-cognitive Traits and Entrepreneurship: The Moderating Role of Economic Institutions." Journal of Business Venturing 34, no. 1: 178-96.

Bowen, Harry P., and Dirk De Clercq. 2008. "Institutional Context and the Allocation of Entrepreneurial Effort." Journal of International Business Studies 39, no. 4: 747-67.

Brammer, Stephen, Layla Branicki, Martina Linnenluecke, and Tom Smith. 2019. "Grand Challenges in Management Research: Attributes, Achievements, and Advancement." Australian Journal of Management 44, no. 4: 517-33.

Buchanan, James M. 1969. Cost and Choice: An Inquiry in Economic Theory. Chicago: Markham Publishing Company.

Burns, Scott. 2018a. "Human Capital and Its Structure." Journal of Private Enterprise 33, no. 2: 33-51.

—_. 2018b. "M-Pesa and the 'Market-Led Approach to Financial Inclusion." Economic Affairs 38, no. 3: 406-21.

Bylund, Per. 2019. "Entrepreneurship and Austrian Economics: Theory, History, and Future." MISES 7, no. 3: 1-4.

—. Forthcoming. "The Firm vs. the Market: The Transaction Cost Theories of Coase and Williamson Dehomogenized." Strategic Management Review.

Bylund, Per, and Matthew McCaffery. 2017. "A Theory of Entrepreneurship and Institutional Uncertainty." Journal of Business Venturing 32, no. 5: 461-75.

Candela, Rosolino A., and Vincent Geloso. 2019. "Coase and Transaction Costs Reconsidered: The Case of the English Lighthouse System." European Journal of Law and Economics 48, no. 3: 331-49. 
Candela, Rosolino A. Forthcoming. "The Role of Transaction Costs in Douglass North's Understanding in the Process of Change in Economic History." Pp. 49-71 in A Companion to Douglass North, ed. Andres Marroquín and Nikolai Wenzel. Guatemala City: Universidad Francisco Marroquín.

Coase, Ronald H. 1937. "The Nature of the Firm." Economica 4, no. 16: 386-405.

— 1960. "The Problem of Social Cost." Journal of Law and Economics 3: 1-44.

—. 1977. "Economics and Contiguous Disciplines." Pp. 481-95 in The Organization and Retrieval of Economic Knowledge: Proceedings of a Conference Held by the International Association at Kiel, West Germany, ed. Mark Perlman. Boulder, Colo.: Westview Press.

_ 1991. "The New Institutional Economics." American Economic Review 82, no. 4: 713-19.

Colombatto, Enrico. 2003. "Why Is Corruption Tolerated?" Review of Austrian Economics 16, no. 4: 363-79.

Cordato, Roy. 2004. "Toward an Austrian Theory of Environmental Economics." Quarterly Journal of Austrian Economics 7, no. 1: 3-16.

Cowan, Robin, and Mario J. Rizzo. 1996. "The Genetic-Causal Tradition and Modern Economic Theory." Kyklos 49, no. 3: 273-317.

Cowen, Tyler, and Richard Fink. 1985. "Inconsistent Equilibrium Constructs: the Evenly Rotating Economy of Mises and Rothbard." American Economic Review 75, no. 4: 866-69.

Coyne, Christopher J., and Peter T. Leeson. 2004. "The Plight of Underdeveloped Countries." Cato Journal 24, no. 3: 235-49.

Coyne, Christopher J., Russell S. Sobel, and John A. Dove. 2010. "The Non-productive Entrepreneurial Process." Review of Austrian Economics 23, no. 4: 333-46.

Cheung, Steven N. S. "The Contractual Nature of the Firm." Journal of Law and Economics 26, no. 1 (1983): 1-21.

Davis, Lance E., Douglass C. North. 1971. Institutional Change and American Economic Growth. New York: Cambridge University Press. 
Demsetz, Harold. 1967. "Toward a Theory of Property Rights." American Economic Review 57, no. 2: 347-359.

DiLorenzo, Thomas J. 1988. "Competition and Political Entrepreneurship: Austrian Insights into Public-Choice Theory." Review of Austrian Economics 2, no. 1: 59-71.

— 1990. "The Subjectivist Roots of James Buchanan's Economics." Review of Austrian Economics 4, no. 1: 180-95.

Dorobantu, Sinziana, Aseem Kaul, and Bennet Zelner. 2017. "Nonmarket Strategy Research through the Lens of New Institutional Economics: An Integrative Review and Future Directions." Strategic Management Journal 38, no. 1: 114-40.

Easterly, William R. 2001. The Elusive Quest for Growth. Cambridge, Mass.: MIT Press.

Eggertsson, Thráinn. 1990. Economic Behavior and Institutions: Principles of Neoinstitutional Economics. London: Cambridge University Press.

Elert, Niklas, and Magnus Henrekson. 2016. "Evasive Entrepreneurship." Small Business Economics 47, no. 1: 95-113.

—_. 2017. "Entrepreneurship and Institutions: A Bidirectional Relationship." IFN Working Paper no. 1153, Research Institute of Industrial Economics, Stockholm, Sweden.

—. 2020. "Entrepreneurship Prompts Institutional Change in Developing Economies." Review of Austrian Economics: 1-21.

Ellickson, Robert C. 2001. "The Market for Social Norms." American Law and Economics Review 3, no. 1: 1-49.

Estrin, Saul, Julia Korosteleva, and Tomasz Mickiewicz. 2013. "Which Institutions Encourage Entrepreneurial Growth Aspirations?" Journal of Business Venturing 28, no. 4: 564-80.

Foss, Kirsten, and Nicolai J. Foss. 2002. "Economic Organization and the Trade-offs between Productive and Destructive Entrepreneurship." Pp. 102-27 in Entrepreneurship and the Firm: Austrian Perspectives on Economic Organization, ed. Nicolai J. Foss and Peter G. Klein. Cheltenham, U.K.: Edward Elgar.

- 2001. "Assets, Attributes and Ownership." International Journal of the Economics of Business 8, no. 1: 19-37. 
Foss, Nicolai J. 1994. "The Theory of the Firm: The Austrians as Precursors and Critics of Contemporary Theory." Review of Austrian Economics 7, no. 1: 31-65.

—. 1997. "Economics, Institutions and Ludwig von Mises." Cultural Dynamics 9, no. 1: 77-96.

— 2012. "The Continuing Relevance of Austrian Capital Theory." Quarterly Journal of Austrian Economics 15, no. 2: 151-71.

Foss, Nicolai J., and Giampaolo Garzarelli. 2007. “Institutions as Knowledge Capital: Ludwig M. Lachmann's Interpretative Institutionalism." Cambridge Journal of Economics 31, no. 5: 789-804.

Foss, Nicolai J., and Peter G. Klein. 2005. "Entrepreneurship and the Economic Theory of the Firm: Any Gains from Trade?" Pp. 55-80 in Handbook of Entrepreneurship Research: Disciplinary Perspectives, ed. Sharon A. Alvarez, Rajshree Agarwal, and Olav Sorenson. Boston: Springer.

- 2009. "Austrian Economics and the Transaction Cost Approach to the Firm." Libertarian Papers 1, no. 39: 1-20.

—. 2012. Organizing Entrepreneurial Judgment: A New Approach to the Firm. New York: Cambridge University Press.

Foss, Nicolai J., Peter G. Klein, and Sandra K. Klein. 2007. "The Entrepreneurial Organization of Heterogeneous Capital." Journal of Management Studies 44, no. 7: 1165-86.

Foss, Nicolai J., Peter G. Klein, Yasemin Y. Kor, and Joseph T. Mahoney. 2008. "Entrepreneurship, Subjectivism, and the Resource-Based View: Toward a New Synthesis." Strategic Entrepreneurship Journal 2, no. 1: 73-94.

Garrison, Roger W. 1995. "Equilibrium and Entrepreneurship." Advances in Austrian Economics 2, part A: 67-78.

- 2001. Time and Money: The Macroeconomics of Capital Structure. London: Routledge.

Garrouste, Pierre. 2008. "The Austrian Roots of the Economics of Institutions." Review of Austrian Economics 21, no. 4: 251.

George, Gerard, Jennifer Howard-Grenville, Aparna Joshi, and Laszlo Tihanyi. 2016. “Understanding and Tackling Societal Grand Challenges 
through Management Research." Academy of Management Journal 59, no. 6: 1880-95.

Glaeser, Edward L., and Andrei Shleifer. 2002. "Legal Origins.” Quarterly Journal of Economics 117, no. 4: 1193-1229.

Hayek, Friedrich A. 1943. "The Facts of the Social Sciences." Ethics 54, no. 1: 1-13.

- 1945. "The Use of Knowledge in Society." American Economic Review 35, no. 4: 519-30.

—. 1948. Individualism and Economic Order. Chicago: University of Chicago Press.

— 1955. The Counter-Revolution of Science. Glencoe, Ill.: Free Press.

—. 1968. "Competition as a Discovery Procedure." Quarterly Journal of Austrian Economics 5, no. 3: 9-23.

Henrekson, Magnus, and Tino Sanandaji. 2011. "The Interaction of Entrepreneurship and Institutions." Journal of Institutional Economics 7, no. 1: 47-75.

Herbener, Jeffrey M. 1996. "Calculation and the Question of Arithmetic." Review of Austrian Economics 9, no. 1: 151-62.

Higgs, Robert. 1997. "Regime Uncertainty: Why the Great Depression Lasted So Long and Why Prosperity Resumed after the War." Independent Review 1, no. 4: 561-90.

High, Jack. 2009. "Entrepreneurship and Economic Growth: The Theory of Emergent Institutions." Quarterly Journal of Austrian Economics 12, no. 3: 3-36.

Holcombe, Randall G. 1998. "Entrepreneurship and Economic Growth." Quarterly Journal of Austrian Economics 1, no. 2: 45-62.

—. 1999. "Entrepreneurship and Economic Growth: Reply.” Quarterly Journal of Austrian Economics 2, no. 2: 73-78.

Horwitz, Steven. 1998. "Monetary Calculation and Mises's Critique of Planning." History of Political Economy 30: 427-29. 
. 2004. "Monetary Calculation and the Unintended Extended Order: The Misesian Microfoundations of the Hayekian Great Society." Review of Austrian Economics 17, no. 4: 307-21.

Hülsmann, Jörg Guido. 1997. "Knowledge, Judgment, and the Use of Property." Review of Austrian Economics 10, no. 1: 23-48.

—. 1999. "Entrepreneurship and Economic Growth: Comment on Holcombe." Quarterly Journal of Austrian Economics 2, no. 2: 63-65.

— . 2004. "The A Priori Foundations of Property Economics." Quarterly Journal of Austrian Economics 7, no. 4: 41-68.

Johnson, Simon, John McMillan, and Christopher Woodruff. 2002. "Property Rights and Finance." American Economic Review 92, no. 5: 1335-56.

Kim, Phillip H., Karl Wennberg, and Grégoire Croidieu. 2016. “Untapped Riches of Meso-level Applications in Multilevel Entrepreneurship Mechanisms." Academy of Management Perspectives 30, no. 3: 273-91.

Kirzner, Israel M. 1966. An Essay on Capital. New York: Augustus M. Kelley.

—. 1971. "Entrepreneurship and the Market Approach to Development." In Toward Liberty: Essays in Honor of Ludwig von Mises on the Occasion of His 90th Birthday, ed. Friedrich August von Hayek. Menlo Park, Calif.: Institute for Humane Studies.

- 1973. Competition and Entrepreneurship. Chicago: University of Chicago Press.

- 1985. Discovery and the Capitalist Process. Chicago: University of Chicago Press.

—. 1996. "Reflections on the Misesian Legacy in Economics." Review of Austrian Economics 9, no. 2: 143-54.

—_. 1997. "Entrepreneurial Discovery and the Competitive Market Process: An Austrian Approach." Journal of Economic Literature 35, no. 1: 60-85.

_ 2009. "The Alert and Creative Entrepreneur: A Clarification." Small Business Economics 32, no. 2: 145-52.

Klein, Peter G. 1999. "Entrepreneurship and Corporate Governance." Quarterly Journal of Austrian Economics 2, no. 2: 19-42. 
- 2000. "New Institutional Economics." In Encyclopedia of Law and Economics, ed. Boudewijn Bouckaert and Gerrit De Geest. Edward Elgar.

—. 2008. “Opportunity Discovery, Entrepreneurial Action, and Economic Organization." Strategic Entrepreneurship Journal 2, no. 3: 175-90.

—_. 2009a. “Risk, Uncertainty, and Economic Organization." Pp. 117-24 in The Capitalist and the Entrepreneur: Essays on Organizations and Markets. Auburn, Ala.: Ludwig von Mises Institute.

_ 2009b. "Williamson and the Austrians." Mises Daily, Oct. 14, 2009. https://mises.org/library/williamson-and-austrians.

Klein, Peter G., and Per L. Bylund. 2014. "The Place of Austrian Economics in Contemporary Entrepreneurship Research." Review of Austrian Economics 27, no. 3: 259-79.

Klein, Peter G., Joseph T. Mahoney, Anita M. McGahan, and Christos N. Pitelis. 2010. "Toward a Theory of Public Entrepreneurship." European Management Review 7, no. 1: 1-15.

Lachmann, Ludwig M. [1956] 1978. Capital and Its Structure. Menlo Park, Calif.: Institute for Humane Studies.

- 1977. Capital, Expectations, and the Market Process. Ed. Walter E. Grinder. Menlo Park, Calif.: Institute for Humane Studies.

—. 1978. "An Interview with Ludwig Lachmann." Austrian Economics Newsletter 1, no. 3.

- 1976. "From Mises to Shackle: An Essay on Austrian Economics and the Kaleidic Society." Journal of Economic Literature 14, no. 1: 54-62.

- 1986. The Market as an Economic Process. New York: Blackwell.

— 2007. The Legacy of Max Weber. Berkeley, Calif.: Glendessary Press.

Langlois, Richard N., ed. 1986. Economics as a Process: Essays in the New Institutional Economics. New York: Cambridge University Press.

. 1992. "Orders and Organizations: Toward an Austrian Theory of Social Institutions." Pp. 165-92 in Austrian economics: Tensions and New Directions, ed. Bruce J. Caldwell and Stephan Boehm. New York: Springer Science and Business Media. 
La Porta, Rafael, Florencio Lopez-de-Silanes, and Andrei Shleifer. 2008. "The Economic Consequences of Legal Origins." Journal of Economic Literature 46, no. 2: 285-332.

Lavoie, Don. 1985. Rivalry and Central Planning: The Socialist Calculation Debate Reconsidered. Cambridge: Cambridge University Press.

Lazear, Edward P. 2004. "Balanced Skills and Entrepreneurship." American Economic Review 94, no. 2: 208-11.

Ledeneva, Alena. 2009. "From Russia with Blat: Can Informal Networks Help Modernize Russia?" Social Research 76, no. 1: 257-88.

Leeson, Peter T. 2012. "An Austrian approach to Law and Economics, with Special Reference to Superstition." Review of Austrian Economics 25, no. 3: 185-98.

- 2017. WTF?!: An Economic Tour of the Weird. Stanford, Calif.: Stanford University Press.

Leeson, Peter T., and Peter J. Boettke. 2009. “Two-Tiered Entrepreneurship and Economic Development." International Review of Law and Economics 29, no. 3: 252-59.

Leeson, Peter T., and Paola A. Suarez. 2015. "Superstition and SelfGovernance." Advances in Austrian Economics 19: 47-66.

Lewin, Peter. 1982. "Pollution Externalities: Social Cost and Strict Liability." Cato Journal 2: 205-29.

- 1998. Capital in Disequilibrium: The Role of Capital in a Changing World. Abingdon, U.K.: Routledge.

Li, David Daokui, Junxin Feng, and Hongping Jiang. 2006. "Institutional Entrepreneurs." American Economic Review 96, no. 2: 358-62.

Lucas, David S., and Caleb S. Fuller. 2017. “Entrepreneurship: Productive, Unproductive, and Destructive-Relative to What?" Journal of Business Venturing Insights 7: 45-49.

_. 2018. "Bounties, Grants, and Market-Making Entrepreneurship." Independent Review 22, no. 4: 507-28.

Manne, Henry G. 2014. "Resurrecting the Ghostly Entrepreneur." Review of Austrian Economics 27, no. 3: 249-58. 
McCaffrey, Matthew. 2018. “William Baumol's “Entrepreneurship: Productive, Unproductive, and Destructive." Pp. 179-201 in Foundational Research in Entrepreneurship Studies: Insightful Contributions and Future Pathways, ed. Golshan Javadian, Vishal Gupta, Dev K. Dutta, Grace Chun Guo, Arturo E. Osorio, and Banu Ozkanzanc-Pan. Cham, Switzerland: Palgrave Macmillan.

McCloskey, Deirdre N. 2010. Bourgeois Dignity: Why Economics Can't Explain the Modern World. Chicago: University of Chicago Press.

Menger, Carl. [1871] 2007. Principles of Economics. Trans. James Dingwall and Bert F. Hoselitz. Auburn, Ala.: Ludwig von Mises Institute.

_ 1883. Studies on the method of social sciences: and political economy in particular. Duncker \& Humblot.

Minniti, Maria. 2008. “The Role of Government Policy on Entrepreneurial Activity: Productive, Unproductive, or Destructive?" Entrepreneurship Theory and Practice 32, no. 5: 779-90.

Mises, Ludwig von. [1920] 1990. Economic Calculation in the Socialist Commonwealth. Trans. S. Adler. Auburn, Ala.: Mises Institute.

—_ [1922] 1951. Socialism: An Economic and Sociological Analysis. Trans. J. Kahane. New Haven, Conn.: Yale University Press.

—_ 1944. Bureaucracy. New Haven, Conn.: Yale University Press.

- [1949] 1998. Human Action: A Treatise on Economics. Scholar's ed. Auburn, Ala.: Ludwig von Mises Institute.

Murphy, Kevin M., Andrei Shleifer, and Robert W. Vishny. 1991. "The Allocation of Talent: Implications for Growth." Quarterly Journal of Economics 106, no. 2: 503-30.

Newman, Patrick. 2019. "Personnel Is Policy: Regulatory Capture at the Federal Trade Commission, 1914-1929." Journal of Institutional Economics 15, no. 6: 1037-53.

North, Douglass C. 1986. "The New Institutional Economics." Journal of Institutional and Theoretical Economics 142, no. 1: 230-37.

- 1990. Institutions, Institutional Change and Economic Performance. Cambridge: Cambridge University Press. 
1994. "Economic Performance Through Time." American Economic Review 84, no. 1: 359-368.

- 2005. Understanding the Process of Institutional Change. Princeton, N.J.: Princeton University Press.

Palagashvili, Liya, Ennio Piano, and David Skarbek. 2017. The Decline and Rise of Institutions: A Modern Survey of the Austrian Contribution to the Economic Analysis of Institutions. Cambridge: Cambridge University Press, 2017.

Palermo, Giulio. 1999. “The Convergence of Austrian Economics and New Institutional Economics: Methodological Inconsistency and Political Motivations." Journal of Economic Issues 33, no. 2: 277-86.

Piano, Ennio E., and Louis Rouanet. 2020. “Economic Calculation and the Organization of Markets." Review of Austrian Economics 33: 331-48.

Powell, Benjamin. 2010. "Some Implications of Capital Heterogeneity." Pp. 124-35 in Handbook on Contemporary Austrian Economics, ed. Peter J. Boettke. Cheltenham, U.K.: Edward Elgar.

Rajan, Raghuram. 2004. "Assume Anarchy." Finance and Development 41, no. 3: 56-57.

Rizzo, Mario J. 1980. “The Mirage of Efficiency.” Hofstra Law Review 8, no. 3: $641-58$.

Rothbard, Murray N. 1979. "The Myth of Efficiency." Pp. 92-98 in Time, Uncertainty, and Disequilibrium, ed. Mario Rizzo. Lexington, Mass.: D. C. Heath.

—. 1982. “Law, Property Rights, and Air Pollution." Cato Journal 2: 55-99.

- 1991. "The End of Socialism and the Calculation Debate Revisited." Review of Austrian Economics 5, no. 2: 51-76.

- . $[1962,1970][2009$. Man, Economy, and State with Power and Market. 2d scholar's ed. Auburn, Ala.: Ludwig von Mises Institute.

Salerno, Joseph T. 1990. "Ludwig von Mises as Social Rationalist." Review of Austrian Economics 4: 26-54

_. 1993. "Mises and Hayek Dehomogenized." Review of Austrian Economics 6, no. 2: 113-46. 
1994. "Reply to Leland B. Yeager on 'Mises and Hayek on Calculation and Knowledge."' Review of Austrian Economics 7, no. 2: 111-25.

Sanandaji, Tino, and Peter T. Leeson. 2013. "Billionaires." Industrial and Corporate Change 22, no. 1: 313-37.

Sautet, Frederic. 2018. "The Battle for the Essence of Entrepreneurship." Review of Austrian Economics 31, no. 1: 123-39.

Schumpeter, Joseph A. 1934. The Theory of Economic Development: An Inquiry into Profits, Capital, Credit, Interest, and the Business Cycle. Trans. Redvers Opie. Cambridge, Mass.: Harvard University Press.

Sima, Josef. 2004. "Praxeology as Law and Economics." Journal of Libertarian Studies 18: 73-90.

Skarbek, David. 2014. The Social Order of the Underworld: How Prison Gangs Govern the American Penal System. New York: Oxford University Press.

Sobel, Russell S. 2008. "Testing Baumol: Institutional Quality and the Productivity of Entrepreneurship." Journal of Business Venturing 23, no. 6: 641-55.

Stalebrink, Odd J. 2004. “The Hayek and Mises Controversy: Bridging Differences." Quarterly Journal of Austrian Economics 7, no. 1: 27-38.

Stenholm, Pekka, Zoltan J. Acs, and Robert Wuebker. 2013. “Exploring Country-Level Institutional Arrangements on the Rate and Type of Entrepreneurial Activity." Journal of Business Venturing 28, no. 1: 176-93.

Storr, Virgil Henry. 2011. “North's Underdeveloped Ideological Entrepreneur." P. 99 in The Annual Proceedings of the Wealth and Well-being of Nations, ed. Emily Chamlee-Wright. Vol. 1, 2008-2009. Beloit, Wisc.: Beloit College Press.

Stringham, Edward Peter. 2001. "Kaldor-Hicks Efficiency and the Problem of Central Planning." Quarterly Journal of Austrian Economics 4, no. 2: 41-50.

Stringham, Edward P. 2010. "Economic Value and Cost Are Subjective." Pp. in 43-66 Handbook on Contemporary Austrian Economics, ed. Peter J. Boettke. Cheltenham, U.K.: Edward Elgar.

Subrick, J. Robert, and Scott Beaulier. 2004. "An Appeal from New to Old (and Middle-Aged) Austrians." Unpublished manuscript. 
Terrell, Timothy. 2015. “Uncertainty, Asset Specificity, and Entrepreneurial Adaptation." Working paper. https://dx.doi.org/10.2139/ssrn.3013157.

Williamson, Claudia R. 2009. “Informal Institutions Rule: Institutional Arrangements and Economic Performance." Public Choice 139, no. 3-4: 371-87.

Williamson, Oliver E. 1975. Markets and Hierarchies: Analysis and Antitrust Implications: A Study in the Economics of Internal Organization. New York: Free Press.

- 1985. The Economic Institutions of Capitalism: Firms, Markets, Relational Contracting. New York: Free Press.

—_. 1991. "Comparative Economic Organization: The Analysis of Discrete Structural Alternatives." Administrative Science Quarterly 36, no. 2: 269-96.

—. 2000. "The New Institutional Economics: Taking Stock, Looking Ahead." Journal of Economic Literature 38, no. 3: 595-613.

Wonnell, Christopher T. 1985. "Contract Law and the Austrian School of Economics." Fordham Law Review 54: 507.

Yeager, Leland B. 1994. "Mises and Hayek on Calculation and Knowledge." Review of Austrian Economics 7, no. 2: 93-109. 